\title{
Buku Cerita Bergambar Sebagai Media Bimbingan Karir Anak Usia Dini
}

\author{
Dinar Mahdalena Leksana, Diana Dwi Jayanti \\ 1) Program Studi Pendidikan Islam Anak Usia Dini, Universitas Islam Lamongan \\ 2) Program Studi Pendidikan Islam Anak Usia Dini, Universitas Islam Lamongan
}

\begin{abstract}
Abstrak
Media yang digunakan dalam pelaksanaan bimbingan dan konseling karir AUD saat ini masih sangat terbatas. Hal ini disebabkan kurangnya pengetahuan tentang jenis-jenis media yang dapat digunakan dalam implementasi layanan bimbingan karir di Pendidikan Anak Usia Dini. Jadi kita membutuhkan media yang sesuai dengan kebutuhan anak usia dini. Sehingga penulis menyusun sebuah media bimbingan karir dalam bentuk cerita bergambar. Media bimbingan cerita bergambar ini dibuat dalam bentuk buku cerita bergambar, penuh warna, dengan cerita sederhana, sehingga mudah dipahami oleh anak usia dini. Penyusunan buku cerita bergambar untuk AUD ini menggunakan metode research and development dari Borg and Gall yang sudah mengalami penyederhaan langkah oleh Syamsudi, dimana dalam penelitian ini melibatkan beberapa ahli dibidang bahasa, dan ahli di bidang bimbingan dan konseling, dan praktisi paud sebagai penjembatan kepada anak usia dini. Hingga tercipta sebuah buku cerita bergambar yang berisi cerita sederhana yang berkaitan tentang jenis-jenis profesi yang ada disekitar.
\end{abstract}

Kunci: Media, Bimbingan Karir, AUD, Cerita Bergambar

\begin{abstract}
The media used in the implementation of AUD career guidance and counseling is still very limited. This is due to the lack of knowledge about the types of media that can be used in the implementation of career guidance services in Early Childhood Education. So we need media that is suitable for the needs of early childhood. So the authors compile a media career guidance in the form of pictorial stories. This picture story guidance media is made in the form of a picture book, full of color, with simple stories, so that it is easily understood by young children. The compilation of picture books for AUD uses the research and development method of Borg and Gall which has undergone a simple step by Syamsudi, where in this study involved several experts in the field of language, and experts in the field of guidance and counseling, and practitioners of paud as a bridge to children early. Until created a picture book that contains simple stories that are related about the types of professions that are around.
\end{abstract}

\section{PENDAHULUAN}

Salah satu aspek penting yang perlu mendapat perhatian dalam kehidupan manusia adalah masalah karier. Hal ini karena karier memiliki keterkaitan yang erat dengan beberapa aspek lain dalam kehidupan manusia seperti, aspek kemandirian ekonomi, kesejahteraan, kepuasan dan pencapaian diri dalam kehidupan. Karier dapat didefinisikan sebagai suatu totalitas kehidupan professional sejak mata terbuka di pagi hari hingga kembali tidur terlelap. Karier tidak semata berhubungan dengan cara-cara memperoleh penghidupan, melainkan terkait erat dengan passion, tujuan hidup, values, dan motivasi dalam berkarya untuk memberikan kontribusi positif bagi lingkungan sekitar (Suhardono, 2010).

Melalui karier seseorang dapat mencapai kebutuhan eksistensinya sebagai seorang individu maupun sebagai anggota masyarakatnya. Karier juga dapat menjadi salah satu sarana seorang individu 
dalam mengekspresikan 'passion' dalam diri untuk dapat mencapai kondisi 'well being' dalam kehidupan kemanusiaannya. Terdapat hal-hal mendasar yang perlu untuk dipahami ketika kita berbicara tentang karier, beberapa hal tersebut antara lain: 1) karier berhubungan dengan pengenalan diri sendiri terkait dengan minat, bakat, kemampuan, dsb; 2) berbicara karier juga berhubungan dengan bagaimana seorang individu menjalani kehidupan yang bermakna; 3) pemilihan karier merepresentasikan pemilihan cara seseorang untuk merepresentasikan nilai-nilai hidup yang dianutnya, 4) karier merupakan motivasi positif yang dapat menggerakkan seseorang ke arah yang lebih positif, 5) karier berbicara tentang bagaimana seseorang dapat mencapau kebahagiaan dan kepuasan/ketercapaian dalam hidup (Suhardono, 2010).

Sebagai salah satu hal yang penting dalam kehidupan, kesadaran karir ini bahkan mungkin perlu untuk diperkenalkan, ditumbuhkan dan kemudian dikembangkan sejak individu berada pada tahap usia dini. Tahap mengenalkan, menumbuhkan, kemudian mengembangkan kesadaran karier dapat dimulai sejak masa anak, dan prosesnya dapat dilakukan salah satunya melalui bimbingan dan konseling karier di lingkungan Pendidikan Anak Usia Dini. El Fiah (2016) mengemukakan bahwa bimbingan dan konseling anak usia dini adalah proses pemberian bantuan kepada anak usia dini yang dilakukan oleh pendidik (guru/pendamping) agar anak dapat tumbuh dan berkembang secara optimal serta memiliki kemampuan mengatasi / menyelesaikan permasalahan-permasalahan yang dihadapinya. Adapun ruang lingkup bimbingan dan konseling pada anak usia dini yaitu; bimbingan pribadi-sosial; bimbingan belajar; dan bimbingan karir.

Berbicara tentang bimbingan dan konseling karier pada pendidikan anak usia dini, dapat dikatakan bahwa keberadaannya pada dasarnya tidak dimaksudkan untuk mengarahkan anak melakukan pilihanpilihan premature terhadap pekerjaan, akan tetapi fokusnya pada kesadaran akan pilihan-pilihan yang akan tersedia, bagaiman cara-cara mengantisipasi dan merencanakannya, serta hubungannya dengan ciri kepribadian setiap anak. Perlu ditekankan kepada anak usia dini bahwa nantinya mereka punya kesempatan yang sama satu sama lain untuk bisa mewujudkan cita-cita mereka. Mengingat betapa pentingnya masalah karier dalam kehidupan manusia, maka sejak dini anak perlu dipersiapkan dan dibantu untuk merencanakan hari depan yang lebih cerah, dengan cara memberikan pendidikan dan bimbingan karier yang berkelanjutan. Hal ini diperkuat oleh penelitian sheldon dan Morgan (2000) mengemukakan bahwa bimbingan karir disekolah terbukti mampu meningkatkan prestasi belajar anak dan konsep diri yang positif serta memiliki pandangan yang jauh mengenai masa depan.

Winkel (2004) menjelaskan bahwa anak usia dini masuk dalam fase kesadaran karier. Usia dari saat lahir samapai umur 15 tahun merupakan usia dimana anak mengembangkan berbagai potensi, pandangan khas, sikap, minat dan kebutuhan-kebutuhan yang dipadukan dalam konsep diri (self-concept structure). Adapun tujuan umum bimbingan dan konseling karier pada anak usia dini meliputi tiga hal berikut: 1) mengembangkan sikap positif terhadap segala jenis pekerjaan; 2) Membawa para siswa untuk menyadari betapa luasnya dunia kerja yang ada; 3) Menekankan jasa dari masing-masing jenis pekerjaan.

Melalui bimbingan dan konseling karier tersebut anak usia dini dibantu untuk mengenal dunia kerja dan dirinya sendiri serta memiliki kesadaran pentingnyakerelaan untuk bekerjasama, dan bertindak secara bertanggung jawab. Upaya pengenalan dan penyadaran diusahakan bertahap dari yang sederhana ke yang lebih kompleks. Dan pada usia ini, kesadaran karir lebih dititik beratkan pada eksplorasi karir dan pengenalan jabatan yang ada dalam lingkungan masyarakat. Walaupun anak belum sampai pada tahap pemilihan karir, namun pemilihan karir sangat dipengaruhi oleh lingkungan keluarga, masyarakat, media, atau faktor lain yang ikut membantu dalam membuat keputusan karir. Sehingga diperlukan kesadaran karir sejak dini.

Perlu adanya proses yang terstruktur, terencana dan dengan metode-metode yang sesuai dengan karakteristik cara belajar anak usia dini ketika ingin mengaplikasikan bimbingan dan konseling karier pada anak usia dini. Namun dalam kenyataannya, ditemui bahwa proses penumbuhan kesadaran karir anak usia dini selama ini masih banyak yang dilakukan hanya melalui pengenalan kepada jenis-jenis pekerjaan yang kebanyakan dilakukan melalui metode ceramah dengan memanfaatkan sisa waktu dari pembelajaran umum di kelas dengan tanpa menggunakan media yang menarik bagi anak. Padahal di sisi lain, anak usia 
dini yang karakteristik pemikirannya belum sampai pada tahap berpikir abstrak, membutuhkan media yang konkret supaya dapat memperoleh gambaran dan pemahaman tentang suatu informasi baru. Sehingga proses pengenalan atas jenis-jenis karir pada anak usia dini yang dilakukan dengan metodemetode konvensional seperti ceramah dan cerita tanpa media, dirasa kurang efektif dalam menumbuhkan kesadaran pada anak usia dini. Dalam pelaksanaan konseling anak usia dini, konselor tidak cukup hanya menggunakan keterampilan verbal. Konselor dapat menggunakan berbagai media dan aktivitas sebagai bantuan untuk mencapai tujuan. Geldard dan Geldard (2012) mengatakan bahwa kombinasi antara keterampilan konseling verbal dengan pengunaan media atau beberapa aktivitas/strategi memberikan kesempatan pada anak untuk bergabung dengan konselor dalam proses terapeutik. Penggunaan media atau aktivitas memungkinkan anak untuk membagi cerita tentang hal-hal yang sensitive.

Oleh karena itu penulis merasa perlu membuat suatu media dalam hal ini berbentuk buku cerita bergambar untuk sebagai bahan media dalam pelaksanaan bimbingan karir di satuan PAUD.

\section{METODE}

Penelitian ini merupakan jenis penelitian pengembangan yang bertujuan untuk mengembangkan suatu produk yakni buku cerita bergambar yang akan digunakan sebagai media dalam pelaksanaan bimbingan karir anak usia dini. Adapun tahap-tahap pelaksanaan penelitian pengembangan ini didasarkan pada prinsip-prinsip yang dikemukakan oleh Borg dan Gall dengan penyederhanaan langkah-langkah menjadi tiga tahap (Samsudi, 2009:92). Subyek dalam penelitian ini antara lain guru dan murid PAUD Bunga Harapan 1 Lamongan. Metode pemilihan subyek menggunakan teknik purposive sampling, yakni suatu teknik menentuan subyek dengan cara menetapkan ciri-ciri khusus yang sesuai dengan tujuan penelitian sehingga diharapkan dapat menjawab permasalahan penelitian. Data yang dikumpulkan dalam penelitian ini terdiri dari data kualitatif. Data kualitatif berupa penilaian deskriptif yang diperoleh dari wawancara dan FGD kepada guru sebagai subyek pengguna buku cerita bergambar, lembar penilaian kelayakan media yang diisi oleh ahli media, serta hasil laporan naratif deskriptif dari catatan lapangan pada proses bimbingan karir di PAUD. Data-data kualitatif dianalisis dengan metode analisis kualitatif dengan teknik koding, horisonalisasi, pengelompokan tema, sampai pada penarikan kesimpulan.

\section{HASIL DAN PEMBAHASAN}

Untuk mengetahui media bimbingan karir yang akan dikembangkan dalam menumbuhkan kesadaran karir anak usia dini di PAUD Bunga Harapan I, maka perlu diadakan observasi terlebih dulu untuk menjawab dan memenuhi kebutuhan tersebut.

Dalam hal ini kita harus tahu mengapa bimbingan dan konseling anak usia dini ini penting adanya. Anak adalah individu yang sedang berkembangmenuju dewasa, dan dalam kenyataannya tidak ada individu- besar maupunkecil, laki-laki maupun perempuan, kaya maupun miskin, di desa atau di kota, yang tidak dihinggapi masalah. Semua orang dapat dihadapkan masalah, tidak terkecuali anak usia dini. Oleh karena itu disinilah perang pentingnya bimbingan dan konseling ada. Karena penyelenggaraan bimbingan dan konseling untuk anak usia dini adalah berhubungan dengan uoaya memfasilitsi inidividu (anak) yang sedang tumbuh dan berkembang pada semua aspek pribadinya, baik aspek fisik, intelektual, emosional, social, moral, maupun spiritualnya. Agar nantinya mampu mengembangkan potensi dirinya, atau yang disebut dengan mencapai tugas perkembangan anak secara optimal.

Sama halnya dalam upaya menumbuhkan kesadaran karir pada anak usia dini. Menurut Rifda El Fiah (24:2016) layanan bimbingan karir adalah bimbingan yang membantu anak dalam perencanaan, pengembangan, dan pemecahan masalah-masalah karier, seperti pemahaman terhadap jabatan dan tugastugas kerja, pemahaman kondisi dan kemampuan diri, pemahaman kondisi lingkungan, perencanaan dan 
pengembangan karier, penyesuaian pekerjaan, dan pemecahan maslah-masalah karier yang dihadapi secara sederhana.

Dari hasil kajian empiris pada studi pendahuluan mengenai keberadaan dan penggunaan media bimbingan karir di PAUD Bunga Harapan I Lamongan telah diketahui bahwa: di PAUD Bunga Harapan I Lamongan telah digunakan Media Bimbingan Karir, namun belum dikatakan maksimal dikarenakan beberapa hal seperti tidak adanya konselor, sarana dan prasarana, kelayakan penyajian, produk media/ tampilan media, biaya dan sebagainya.

Oleh karena itu perlu dilakukan pengembangan guna menyempurnakan media bimbingan karir dan memaksimalkan layanan bimbingan karir. Secara khusus media bimbingan karir cerita bergambar untuk menumbuhkan kesadaran karir anak, belum pernah dikembangkan di sana, sementara media cerita bergambar dirasa sangat sesuai untuk anak-anak, karena sifatnya yang menarik, dan mencolok. Sedangkan menumbuhkan kesadaran karir sejak dini itu dianggap penting karena akan mempengaruhi sikap anak dalam mengambil keputusan dimasa datang.

Tidak adanya media penunjang yang digunakan dalam kegiatan bimbingan karier, dan tidak adanya need asessmen yang dilakukan agar materi yang diberikan sesuai dengan apa yang dibutuhkan anak, keterbatasan biaya untuk mengembangakan media bimbingan menjadi lebih baik, karena akan membutuhkan biaya yang besar, dan berbagai alasan lain yang disampaikan diatas, menunjukkan bahwa guru kelas yang bertindak sebagai guru BK perlu media yang didalamnya memuat semua yang dibutuhkan anak, sehingga anak dapat menggunakan, dan dapat menumbuhkan kesadaran karier anak dengan tepat dan efektif.

Berdasarkan alasan-alasan yang telah dijelaskan diatas, maka agar media bimbingan karir yang digunakan di PAUD Bunga Harapan I Lamongan lebih optimal dalam menumbuhkan kesadaran karir, lebih sesuai dengan kebutuhan anak, dan menarik, maka disusunlah media bimbingan karir cerita bergambar, dan dengan ini secara langsung media bimbingan karir yang ada di PAUD Bunga Harapan I Lamongan telah dikembangkan dengan inovasi baru. Diharapkan dengan adanya media bimbingan karir cerita bergambar ini dapat memudahkan guru kelas sebagai guru BK/ Konselor dalam melaksanakan bimbingan karir secara optimal, dan memudahkan tercapainya tugas perkembangan karir, khususnya kesadaran karir.

Adapun bentuk pengembangan media bimbingan karier berbasis cerita bergambar untuk menumbuhkan kesadaran karir anak usia dini dijelaskan sebagai berikut:

\section{a. Pengantar}

Media bimbingan karir yang dikembangkan ini adalah media bimbingan karir yang berbebentuk buku cerita bergambar, yang berfokus dalam upaya menumbuhkan kesadarn karir anak, akan jenis-jenis profesi yang ada disekitar mereka. Buku terbuat dari bahan hard paper, tebal, tetapi ringan sehingga aman untuk anak, dan tidak mudah sobek.

Disamping setiap gambar terdapat cerita singkat yang menggambarkan kondisi gambar sehingga untuk anak-anak yang sudah bisa membaca, tentu ini akan menarik, tetapi bagi anak-anak yang belum bisa membaca mereka bisa denga mudah memahami isi cerita hanya melalui gambar. Atau selain itu guru juga bisa berperan untuk membacakan buku tersebut.

Diakhir buku terdapatg dua game board, yang pertama yaitu memcocokkan, dan yang kedua maze, hal ini tentu lebih menambah ketertarikan anak pada buku. Buku dibuat fullcolor sehingga tidak membuat anak bosan. Setiap halam diberi warna beda dengan halaman lainnya.

\section{b. Komponen Media}

Media ini terdiri dari 32 halaman, 14 halaman berupa gambar, 14 halaman berupa cerita, dua halaman sampul dan dua halaman evaluasi berupa game board. Isi cerita terdiri dari 14 jenis profesi yang ada. 


\section{c. Uji Kelayakan Media}

Tujuan dari uji kelayakan adalah menetapkan kesesuaian antara isi media dengan kebutuhan anak. Secara operasional, proses uji kelayakan dimaksudkan untuk memantapkan; 1) kelengkapan dan kebutuhan media; dan 2) kelayakan media yang telah dirumuskan untuk diterapkan disekolah sasaran.

\section{Kelayakan Media Buku Cerita Bergambar dalam Pelaksanaan Bimbingan Karir di PAUD}

Pengkajian secara komprehensif terhadap media bimbingan karir cerita bergambar yang digunakan untuk mencapai tujuan dari validasi rasional. Peneliti menyampaikan media yang disertai dengan instrument penilaian yang berbentuk skala (data kuantitatif) dan saran/ masukan (data kualitatif). Dengan demikian validator dapat memvalidasi media yang dibuat dengan teknik respon terperinci. Sehingga nantinya akan dapat dilihat apakah media bimbingan karir yang sudah di buat dapat digunakan atau diterapkan pada anak usia dini di Satuan PAUD Bunga Harapan 1.

Untuk memperoleh hasil yang maksimal, maka media bimbingan karir cerita bergambar ini telah divalidasi oleh dua ahli bimbingan dan konseling. Salah satu ahli dengan kualifikasi akademik S2 yang sedang menempuh S3 Bimbingan dan Konseling dan salah seorang validator ahli berkualifikasi akademik S2 Bahasa Indonesia. Aspek yang dinilai oleh validator ahli bimbingan dan konseling, antara lain: Rasional, Tujuan, Landasan Hukum yang berkaitan dengan kegiatan layanan, isi cerita, karakteristik media bimbingan karir cerita bergambar, langkah-langkah penyusunan media, komponen media bimbingan karir, evaluasi dan indicator yang dilakukan sesuai dengan target intervensi yang ingin dicapai. Sedangkan validator ahli berkualifikasi pendidikan S2 bahasa indonesia, aspek yang dinilai antara lain: bahasa dan keterbacaan media.

Selain divalidasi oleh para pakar, model ini juga telah divalidasi oleh praktisi di lapangan dalam hal ini guru PAUD yang berbeda sebanyak 11 orang. Validasi praktisi aspek yang dinilai adalah kontribusi media terhadap pencapaian tujuan pendidikan dan tujuan bimbingan dan konseling, peluang keterlaksanaan, bimbingan karir menggunakan media cerita bergambar, kemampuan konselor dalam menggunakan media, kesesuaian model dengan karateristik anak, kepraktisan model untuk dipahami, dan peluang keterjalinan kerjasama dalam pelaksanaan media.

Hasil validasi oleh masing-masing validator dideskrepsikan sebagai berikut:

\section{Pakar}

Berdasarkan hasil diskusi dalam proses bimbingan oleh kedua pakar ahli, media yang telah didesain oleh peneliti berdasarkan penelitian pendahuluan, dan analisis kebutuhan anak, yang dibuat dalam bentuk prototype menurut para pakar, media sudah dapat digunakan dalam uji keefektitasan setelah perbaikan dalam beberapa aspek, seperti penulisan, kesesusaian gambar dengan materi utama, dan warna latar media.

Media bimbingan karir cerita bergambar yang sudah direvisi selanjutnya dapat digunakan, dan diteruskan untuk diuji coba keefektifitasannya sebagai salah satu media bimbingan karir anak usia dini di satuan PAUD.

\section{Praktisi}

Selain divalidasi oleh para pakar, model ini juga telah divalidasi oleh praktisi di lapangan dalam hal ini guru PAUD yang ada di wilayah kecamatan lamongan, sebanyak 11 orang yang masing masing memiliki kualifikasi akademik S1. Validasi praktisi aspek yang dinilai adalah kontribusi media yang didesain terhadap pencapaian tujuan pendidikan dan tujuan bimbingan dan konseling, peluang keterlaksanaan, kemuampuan guru/ konselor dalam menerapkan media, kesesuaian media dengan karateristik anak, kepraktisan media untuk dipahami, dan peluang keterjalinan kerjasama dalam pelaksanaan media.

Penilaian hasil validasi praktisi dijelaskan dalam table berikut:

\section{Tabel.1 Deskripsi Hasil Validasi Praktisi}




\begin{tabular}{|c|c|c|c|c|}
\hline Praktisi & $\begin{array}{l}\text { Total } \\
\text { Skor }\end{array}$ & Nilai & Simpulan & $\begin{array}{l}\text { Komentar, Saran, dan } \\
\text { Perbaikan }\end{array}$ \\
\hline 1 & 19 & $\begin{array}{l}\text { Sangat } \\
\text { baik }\end{array}$ & $\begin{array}{l}\text { Model ini Sudah dapat } \\
\text { digunakan dengan sedikit } \\
\text { penyempurnaan sesuai saran }\end{array}$ & $\begin{array}{l}\text { Model sudah cukup baik } \\
\text { namun harus dikembangkan } \\
\text { dari materinya belum fariatif } \\
\text { dan kreatif lagi }\end{array}$ \\
\hline 2 & 21 & $\begin{array}{l}\text { Sangat } \\
\text { Baik }\end{array}$ & $\begin{array}{l}\text { Model ini Sudah dapat } \\
\text { digunakan dengan sedikit } \\
\text { penyempurnaan sesuai saran }\end{array}$ & $\begin{array}{l}\text { Gambar dindari yang bersifat } \\
\text { kekerasan }\end{array}$ \\
\hline 3 & 18 & Baik & $\begin{array}{l}\text { Media ini membutuhkan } \\
\text { beberapa perbaikan sebelum } \\
\text { digunakan }\end{array}$ & Tulisannya kurang besar \\
\hline 4 & 19 & $\begin{array}{l}\text { Sangat } \\
\text { Baik }\end{array}$ & $\begin{array}{l}\text { Model ini Sudah dapat } \\
\text { digunakan dengan sedikit } \\
\text { penyempurnaan sesuai saran }\end{array}$ & $\begin{array}{l}\text { Media sudah baik namun perlu } \\
\text { beberapa perbaiakan dalam } \\
\text { penggunaan bahasa yang lebih } \\
\text { bisa dipahami anak }\end{array}$ \\
\hline 5 & 18 & Baik & $\begin{array}{l}\text { Media ini membutuhkan } \\
\text { beberapa perbaikan sebelum } \\
\text { digunakan }\end{array}$ & $\begin{array}{l}\text { Untuk materi pokok } \\
\text { bahasannya kalau bisa } \\
\text { ditambah lagi. }\end{array}$ \\
\hline 6 & 20 & $\begin{array}{l}\text { Sangat } \\
\text { Baik }\end{array}$ & $\begin{array}{l}\text { Model ini Sudah dapat } \\
\text { digunakan dengan sedikit } \\
\text { penyempurnaan sesuai saran }\end{array}$ & $\begin{array}{l}\text { Isi media sudah menarik, hanya } \\
\text { perlu direvisi tampilan awal } \\
\text { dan penulisan masih banyak } \\
\text { yang salah }\end{array}$ \\
\hline 7 & 17 & Baik & $\begin{array}{l}\text { Media ini membutuhkan } \\
\text { beberapa perbaikan sebelum } \\
\text { digunakan }\end{array}$ & $\begin{array}{l}\text { Dan perlu penyempurnaan } \\
\text { terhadap sampul/ cover yang } \\
\text { lebih menarik }\end{array}$ \\
\hline 8 & 20 & $\begin{array}{l}\text { Sangat } \\
\text { Baik }\end{array}$ & $\begin{array}{l}\text { Model ini Sudah dapat } \\
\text { digunakan dengan sedikit } \\
\text { penyempurnaan sesuai saran }\end{array}$ & $\begin{array}{l}\text { Isi media bimbingan } \\
\text { multimedia ini isinya sudah } \\
\text { menarik, perlu direvisi pada } \\
\text { tampilan prasarana yang } \\
\text { dibutuhkan }\end{array}$ \\
\hline 9 & 20 & $\begin{array}{l}\text { Sangat } \\
\text { Baik }\end{array}$ & $\begin{array}{l}\text { Model ini Sudah dapat } \\
\text { digunakan dengan sedikit } \\
\text { penyempurnaan sesuai saran }\end{array}$ & $\begin{array}{l}\text { Media bimbingan karir direvisi } \\
\text { cover/ tampilan awal yang } \\
\text { kurang menarik, dan penulisan } \\
\text { kata yang masih banyak ada } \\
\text { yang salah }\end{array}$ \\
\hline 10 & 21 & $\begin{array}{l}\text { Sangat } \\
\text { Baik }\end{array}$ & $\begin{array}{l}\text { Model ini Sudah dapat } \\
\text { digunakan dengan sedikit } \\
\text { penyempurnaan sesuai saran }\end{array}$ & $\begin{array}{l}\text { Gambar dindari yang bersifat } \\
\text { kekerasan }\end{array}$ \\
\hline 11 & 20 & $\begin{array}{l}\text { Sangat } \\
\text { Baik }\end{array}$ & $\begin{array}{l}\text { Model ini Sudah dapat } \\
\text { digunakan dengan sedikit } \\
\text { penyempurnaan sesuai saran }\end{array}$ & $\begin{array}{l}\text { Isi media bimbingan } \\
\text { multimedia ini isinya sudah } \\
\text { menarik, perlu direvisi pada } \\
\text { tampilan prasarana yang } \\
\text { dibutuhkan }\end{array}$ \\
\hline
\end{tabular}


Tabel.2 Deskripsi Hasil Validasi Pakar

\begin{tabular}{|l|l|l|l|l|}
\hline Pakar & $\begin{array}{l}\text { Total } \\
\text { Skor }\end{array}$ & Nilai & \multicolumn{1}{|c|}{ Simpulan } & \multicolumn{1}{|c|}{$\begin{array}{c}\text { Komentar, Saran, dan } \\
\text { Perbaikan }\end{array}$} \\
\hline 1 & 19 & $\begin{array}{l}\text { Sangat } \\
\text { Baik }\end{array}$ & $\begin{array}{l}\text { Model ini sudah dapat digunakan } \\
\text { dengan sedikit penyempurnaan } \\
\text { sesuai saran }\end{array}$ & Gambar Lebih dibuat sederhana \\
\hline 2 & 21 & $\begin{array}{l}\text { Sangat } \\
\text { Baik }\end{array}$ & $\begin{array}{l}\text { Model ini Sudah dapat digunakan } \\
\text { dengan sedikit penyempurnaan } \\
\text { sesuai saran }\end{array}$ & $\begin{array}{l}\text { Hindari gambar yang } \\
\text { menggunakan senjata taajam } \\
\text { yang menyebabkan ambigu }\end{array}$ \\
\hline 3 & 18 & Baik & $\begin{array}{l}\text { Media ini membutuhkan beberapa } \\
\text { perbaikan sebelum digunakan }\end{array}$ & $\begin{array}{l}\text { Isi cerita lebih dipersingkat pada } \\
\text { maksud cerita }\end{array}$ \\
\hline 4 & 20 & $\begin{array}{l}\text { Sangat } \\
\text { Baik }\end{array}$ & $\begin{array}{l}\text { Media ini dapat digunakan dengan } \\
\text { tambahan revisi }\end{array}$ & $\begin{array}{l}\text { Gunakan kertas yang aman } \\
\text { untuk anak usia dini }\end{array}$ \\
\hline
\end{tabular}

\section{SIMPULAN}

Berdasarkan dari hasil paparan penelitian dan sajian data diatas, maka dapat disimpulkan bahwa media bimbingan karir dalam bentuk cerita bergambar ini dapat digunakan di PAUD Bunga Harapan 1, karena sesuai dengan karakteristik anak, dan menjadi referensi media bimbingan karir Anaka Usia Dini di satuan PAUD lain yang memiliki kesamaan karakteristik dengan PAUD Bunga Harapan 1, selain itu harapan dari penulis adalah, media bimbingan karir cerita bergambar ini juga menjadi sebagai salah satu upaya untuk menumbuhkan semangat gemar membaca sejak dini.

\section{DAFTAR PUSTAKA}

Arikunto, Suharsimi. 2006. "Prosedur penelitian suatu pendekatan praktik". Jakarta: PT Rineka Cipta

Abraham H. Maslow. 2010. Motivation and Personality. Rajawali : Jakarta

Borg \& Gall,2003. Education Research. New York : Allyn and Bacon.

Djamarah, Syaiful Bahri dan Aswan Zain. 2010. Strategi Belajar Mengajar. Jakarta: Rineka Cipta.

Gysbers, N.C., \& Henderson, P. (2000). Developing \& Managing Your School Guidance Program. Alexandria: American Counseling Association.

Herr,E.L dan SH. Cramer.1979, Career Guidance and Counseling Througth The life Span, Bouston : Brown dan Company.

Hurlock, B. Elizabeth. 1993. Psikologi Perkembangan. Jakarta: Erlangga.

Izzaty, Rita E., dkk. 2017. Model Konseling Anak Usia Dini. Bandung: Rosda Karya

KBBI, 2016. Kamus Besar Bahasa Indonesia (KBBI). [Online] Available at: http://kbbi.web.id/pusat, [Diakses 21 Juni 2016].

Syah,Muhibin,2005. Psikologi Belajar. Jakarta : PT Raja Grafindo Persada.cet keempat

Sugiyono.2008. Metode Penelitian Pendekatan Kualitatif dan $R \& D$. Bandung: Alfabeta .

Suhardono, Rene. 2010. Your Job Is Not Your Career. Tangerang: Literati 
Stake, R.E.1995. The Art of Case Study Research. Thousand Oaks, CA: Sage Publishing

Winkel, W.S. 2004. Bimbingan dan Konseling di Institusi Pendidikan. Jakarta :PT. Gramedia.

Yin, R.K.2009.Case Study Reasearch: Desain and Method (4th ed). Thousand Oaks, CA: Sage Publishing. 